Nowoczesne Systemy Zarządzania

Zeszyt 12 (2017), nr 2 (kwiecień-czerwiec)

ISSN 1896-9380, s. 63-80

Modern Management Systems

Volume 12 (2017), No. 2 (April-June)

ISSN 1896-9380, pp. 63-80
Instytut Organizacji i Zarządzania

Wydział Cybernetyki

Wojskowa Akademia Techniczna

w Warszawie

Institute of Organization and Management Faculty of Cybernetics

Military University of Technology

\title{
Retoryka na usługach zarządzania
}

\section{Retoria on management services}

\author{
Joanna K. Skulska \\ Wojskowa Akademia Techniczna, Wydział Cybernetyki \\ joannaskulska@o2.pl
}

\begin{abstract}
Abstrakt. Dobra komunikacja wewnątrz firmy jest podstawą jej funkcjonowania, stanowi remedium na wszelkie możliwe trudności związane z zarządzaniem kadrą pracowniczą, jest jednym z najważniejszych narzędzi zarządzania, narzędziem zapewniającym efektywne działania. Skuteczne zarządzanie procesami komunikowania się oraz wysokie kompetencje w zakresie komunikacji perswazyjnej to jedne z podstawowych i najważniejszych zadań menadżerów. Retoryka dostarcza nieograniczony zasób zasad, metod, chwytów, struktur umożliwiających maksymalizowanie potencjalnych korzyści płynących z poprawnej, jasnej i nastawionej na konkretny cel perswazyjnej komunikacji. Jednocześnie znajomość tych zasad jest środkiem do minimalizowania ewentualnych problemów czy przezwyciężania barier komunikacyjnych. Brak znajomości reguł retorycznych stosowanych w celu uskutecznienia komunikacji jest jedną z najpoważniejszych przeszkód na drodze do efektywnej działalności grupowej.
\end{abstract}

Słowa kluczowe: retoryka, perswazja, manipulacja, zarządzanie, komunikacja, akty mowy.

Abstract. Good communication inside the company is the basis of its operation, remedy for all possible difficul-ties related to the management of employees, is one of the most important management tools, an effective tool. Effective communication management and high persuasive communication skills are among the core and most important tasks of managers. Rhetorics provides an unlimited set of rules, methods, tricks, structures to maxim-ize the potential benefits of a correct, clear, and targeted, persuasive communication. At the same time knowledge of these principles is a means of minimizing possible problems or overcoming communication barri-ers. Lack of knowledge of the rhetorical rules used to improve communication is one of the most important obstacles to effective group work.

Keywords: rhetoric, persuasion, manipulation, management, communication, speech acts. 


\section{Wstęp}

Od drugiej połowy XX w. widoczne jest rosnące zainteresowanie sztuką retoryki. Potwierdza to analiza rynku wydawniczego, chociażby tylko w naszym kraju. Można zaobserwować znaczący wzrost liczby publikacji związanych z teorią argumentacji, erystyką, negocjacjami, reklamą, propagandą czy nawet bezpośrednio z samą retoryką. W ramach badań językoznawczych, psychologicznych, socjologicznych szczególnie zaawansowany stał się obszar badań, mający za przedmiot dociekań język komunikowania interpersonalnego. Zjawisko to ma związek między innymi $z$ dynamicznym rozwojem środków masowego przekazu, rosnącym zaangażowaniem wyborców w życie polityczne, jak również ze zmianami społeczno-gospodarczymi. Nic zatem dziwnego, że i w obszarze zarządzania zaczęto wnikliwie analizować mechanizmy wpływania na ludzkie działania, postawy czy przekonania. U podstaw tego zainteresowania leży fakt, że argumentacja obecna jest na każdym etapie życia społecznego (w najszerszym tego słowa znaczeniu): od rodzinnych dyskusji czy rozmów w gronie znajomych, aż po debaty parlamentarne czy rozprawy sądowe. Dialogiczna struktura i argumentacja są kanwą naturalnego dyskursu komunikacyjnego; mowa tu o wszelkich rodzajach wspólnego podejmowania decyzji, uzgadniania wspólnego punktu widzenia, prowadzenia sporów, kłótni, udowadniania czemuś/ komuś słuszności, bądź odmawiania jej. Przemiany społeczno-gospodarcze, zmiana rynku pracy, rozrastające się korporacje, zmiana organizacji pracy, nieustający wymóg podejmowania decyzji pod presją czasu, wydawania poleceń, przekonania odbiorców do własnych racji (podwładnych, przełożonych, klientów itp.) to naturalne środowisko menadżerów. Na każdym poziomie życia społecznego (nawet wśród nisko cywilizowanych populacji) występują nieustannie jakieś konflikty i niezgodności poglądów, ścierają się rozmaite koncepcje, ideologie. To powód, dla którego zaczęto się baczniej przyglądać mechanizmom wpływania na innych i analizować je.

Do łask powróciła zapomniana już niegdyś retoryka $\mathrm{z}$ całym swoim zasobem chwytów, z odpowiednią strukturą, stylem wypowiedzi, sposobem zwracania się do słuchaczy. Coraz powszechniej w świecie uważa się, że w każdej dziedzinie sukces zależy od opanowania sztuki skutecznego komunikowania się. Retoryka w swej nowej, uwspółcześnionej odsłonie - traktowana jako nauka funkcjonalnego i sprawnego posługiwania się językiem w mowie i piśmie, traktowana jako dziedzina interdyscyplinarna, wykorzystująca najnowsze osiągnięcia techniki - dostarcza narzędzi niezbędnych do przeprowadzania analiz różnych sposobów nakłaniania, perswazji i językowych manipulacji.

Celem niniejszego artykułu jest: ukazanie możliwości, jakie daje zastosowanie zasad retoryki w komunikowaniu w organizacji, ukazanie sposobów usprawnienia zarządzania kadrą pracowniczą, zwiększenie efektywności działania pracowników poprzez zwiększenie kompetencji w zakresie komunikacji perswazyjnej menadżera. 


\section{Podstawowe pojęcia i funkcje procesu komunikowania w zarządzaniu}

Etymologia słowa komunikacja prowadzi do łacińskiego czasownika communicare, czyli „czynić wspólnym”, który z kolei pochodzi od przymiotnika communis, czyli wspólny, dającego początek słowu komuna, wspólnota, coś wspólnego, powszechnego (Adair, 2009, s. 17). Komunikację możemy rozumieć zatem jako przekazanie informacji, pojęć, idei i uczuć w taki sposób, aby miały takie samo znaczenie dla nadawcy i odbiorcy.

Termin „komunikacja” jest terminem wieloaspektowym. Za E. Masłyk-Musiał wymienić można dwa podstawowe ujęcia tego procesu. Pierwsze ujęcie jakościowe, w którego skład wchodzą ujęcia przedmiotowe, poznawcze (decyzyjne) oraz wartościujące. Drugie ujęcie ilościowe, na które składają się ujęcia łącznościowe (sterujące), rzeczowe (relacje pomiędzy człowiekiem a maszyną) i abstrakcyjne (Masłyk-Musiał, 1975, s. 12). Na potrzeby niniejszego artykułu, w którym poruszane są kwestie komunikacji w zarządzaniu, istotna jest perspektywa jakościowa komunikacji, czyli związana z przekazywaniem treści na poziomie interpersonalnym (Shuter, New York 1979, s. 26). Poziom interpersonalny zakłada, że jest to proces dwustronny, który można scharakteryzować jako przekazywanie informacji pomiędzy nadawcą i odbiorcą za pośrednictwem odpowiednich kanałów. Interpersonalność zakłada również wzajemne oddziaływanie na siebie osób uczestniczących w procesie. H. Guetzkow pisze, że „komunikacyjny system to wzory przekazywania i interpretacji wiadomości wśród jednostek organizacyjnych oraz pomiędzy tymi jednostkami i ich organizacyjnym otoczeniem" (Guetzkow, Chicago 1965, s. 18). Mówiąc o komunikacji w organizacjach, należy zwrócić uwagę, że jest ono silnie powiązane z podstawowymi funkcjami zarządzania. Mowa tu o takich funkcjach, jak: planowanie, organizowanie, motywowanie oraz kontrola. Szczególną uwagę w tym aspekcie należy zwrócić na zrozumienie form i treści przekazu. W dużej mierze wpływ na nie mają indywidualne percepcje uczestników procesu komunikacji oraz bariery wiedzy i umiejętności, które pomiędzy nimi zachodzą.

Planowanie - jak zauważa J. Stankiewicz - „wymaga umiejętności komunikowania się w czasie prognozowania oraz w trakcie programowania zmierzającego do ustalenia pewnych norm opisu celów działalności organizacji, a także kierunków, sposobów i środków ich realizacji" (Stankiewicz, 2006, s. 15).

Organizowanie to proces budowania zespołu, dobierania personelu tak, aby w pełni móc wykorzystać potencjał pracowników oraz wzmocnić efektywność działań. Znaczące miejsce w tym obszarze ma integracja, wzajemna więź pomiędzy pracownikami. Zbudowanie takiego zespołu wymaga dużych umiejętności po stronie komunikacji interpersonalnej, które zapewnią m.in. efektywne kierowanie, zaakceptowanie przez grupę, rozwiązywanie konfliktów itp. Zadaniem menadżera 
jest rozpoznać odpowiednio potencjał pracowników i ich zdolności, co wymaga znajomości technik wywiadu i obserwacji (Ober, 2013, s. 259).

Skuteczne motywowanie pracowników wymaga empatii (Stankiewicz, 2006, s. 16). Aby rozumieć zachowania i pobudki pracowników, niezbędna jest wiedza na temat bodźców, które pracownika będą stymulowały. Menadżer powinien zatem posiadać umiejętność słuchania, nawiązywania kontaktu, budowania relacji, wymiany wiedzy, związanych z ambicjami, planami, wątpliwościami.

Na płaszczyźnie kontrolowania z perspektywy komunikowania znaczącą rolę odgrywa obiektywizm oraz przekazanie pracownikom w sposób dla nich zrozumiały wszystkich norm, poleceń i zaleceń, które będą oceniane podczas kontroli.

B. Malinowski uważał, że prymarną funkcją języka jest koordynowanie wspólnego działania ludzi, co wymusza jego celowe użycie. „Słowo jest bodźcem warunkującym ludzkie działanie" (Malinowski, 1987, s. 109). Owo celowe działanie zostało dokładnie określone przez W. Pisarka, który stwierdza, że „Ludzie mówią i piszą (...) po to:

- $\quad$ żeby inni widzieli, co zdaniem mówiących i piszących wiedzieć powinni;

- żeby wyrazić, co się mówiącym i piszącym podoba, a czego nie znoszą;

- żeby inni myśleli, odczuwali, postępowali i oceniali rzeczywistość tak, jak mówiący i piszący uważają za właściwe;

- ̇eby utrzymać kontakt i czuć więź z innymi ludźmi;

- żeby wyrazić lub wywołać przeżycia estetyczne, a czasem też

- żeby wyjaśnić lub skomentować użyte środki językowe" (Pisarek, 2002, s. 15).

W. Dmowski wyróżnia trzy rodzaje potrzeb społecznych, które mają wpływ na realizowanie procesu komunikowania się (Domachowski, 1991, s. 103):

- potrzebę przyłączenia (posiadania poczucia, że jest się uczestnikiem jakiejś relacji społecznej);

- potrzeby posiadania kontroli nad otoczeniem (rozumianą również jako możliwości wywierania wpływu w relacjach formalnych oraz relacjach nieformalnych);

- potrzeby przywiązania (otoczenie opieką innych lub przeświadczenie, że inni opiekują się nami).

Za literaturą przedmiotu wyróżnia się dwa poziomy komunikacji:

1. treściowy: ludzie komunikują się ze sobą w określonym celu (przekazanie lub wymiana informacji, wyrażenie opinii, sugestii, etc.).

2. emocjonalny: ludzie komunikują się ze sobą, budując wzajemne relacje (np. poprzez okazywanie solidarności i wsparcia, okazywanie sympatii lub antagonizmów, uwalnianie napięcia).

A. Szewczyk zwraca uwagę na funkcje, które może pełnić w organizacji proces komunikacji w organizacji. Są nimi (Szewczyk, 2004, s. 62):

- funkcja informacyjna - przekazywanie i pozyskiwanie informacji w celu podjęcia konkretnych działań, decyzji, osiągnięcia określonych celów; 
- funkcja kontrolna - sprawowanie kontroli, egzekwowanie powinności, wyznaczanie ról społecznych, obowiązków względem siebie i innych;

- funkcja emotywna - umożliwia wyrażanie uczuć, pozwala na ekspresję emocji, daje szansę na zaspokojenie potrzeb psychospołecznych;

- funkcja motywacyjna - zachęca do podejmowania określonych czynności, zmiany zachowań, osiągania celów.

Język to najbardziej złożony kod używany przez człowieka, za pomocą którego kontaktuje się on ze światem. Posługiwanie się językiem to akt mowy. Naturalną jednostką mowy jest wypowiedź. Za jej pośrednictwem reagujemy na wypowiedź poprzednią, na zadane pytanie, przedstawioną sugestię. Każda wypowiedź ma więc swoją treść i sens. W konkretnej wypowiedzi nie tylko komunikujemy określone treści, ale tworzymy nowe fakty i zdarzenia. Posługując się językiem, wypowiadając pewne słowa i zdania, każdy z nas coś stwierdza, odnosi się do czegoś, ocenia, albo też o coś pyta, czy obiecuje. Oznacza to, że skutki naszych zachowań werbalnych mogą być różne, przynosić odmienne efekty.

Żeby zaistniał proces komunikowania, musi być spełniony podstawowy warunek dotyczący wystąpienia podstawowych elementów tego procesu: nadawca komunikatu - osoba mówiąca w danej chwili; odbiorca komunikatu - osoba słuchająca; komunikat - czyli to, co w trakcie rozmowy jest przekazywane przez nadawcę do odbiorcy; przedmiot rozmowy; kod rozmowy - język (ten sam, znany obu stronom); medium - środek przekazu komunikatu (np. narządy artykulacyjne, nasze ciało).

Zjawisko porozumiewania się jest jednak bardziej złożone i dynamiczne niż wynika $\mathrm{z}$ wyżej przedstawionych elementów. Należy pamiętać, że między powyższymi elementami zachodzą określone relacje, a ich współdziałanie doprowadza do tego, że rozmowa jest aktywnym spotkaniem ludzi. Łatwo zatem zauważyć, że proces komunikowania się rozpoczyna się wówczas, gdy pojawia się intencja w postaci myśli, zamiaru lub uczucia, z jaką nadawca pragnie podzielić się z odbiorcą. Odbiorca poznaje ją wówczas, gdy zostanie ona przełożona na informację. Informacja ta musi być dostępna i czytelna dla drugiej osoby. Będzie ona wówczas taka, gdy zachowania nadawcy będą pełniły funkcje znaków, a także nośników określonych wiadomości. Znakami mogą być zatem zachowania werbalne (wypowiedzi słowne) i/lub niewerbalne (gesty, mimika).

Efektem w procesie komunikacji powinno być osiągnięcie sytuacji, w której cel nadawcy będzie właściwie zrozumiany, a w następstwie zrealizowany przez odbiorcę. Proces komunikowania się rozpoczyna się wówczas, gdy pojawia się intencja w postaci myśli, zamiaru lub uczucia, z jaką nadawca pragnie podzielić się z odbiorcą. Odbiorca poznaje ją wówczas, gdy zostanie ona przełożona na informację. Informacja ta musi być dostępna i czytelna dla drugiej osoby. Będzie ona wówczas taka, gdy zachowania nadawcy będą pełniły funkcje znaków, a także nośników określonych wiadomości. Znakami mogą być zatem zachowania werbalne (wypowiedzi słowne) i/lub niewerbalne (gesty, mimika). 
Przekładając proces komunikacji na poziom organizacji, nadawcą jest osoba, która ma informację, potrzebę, chęć lub obowiązek służbowy jej przekazania innej osobie lub grupie osób (Ober, 2007, s. 9). Kolejnym krokiem jest zakodowanie informacji, czyli przekształcenie w symbole, np. pismo, schemat, wykres, obraz czy gest. Sposób kodowania uzależniony jest od nadawcy. Powinien on przy kodowaniu wziąć pod uwagę m.in.: ważność komunikatu, stopień jego ustrukturyzowania, możliwości wyboru nośnika, warunki komunikacji i charakter kontaktu (Ober, 2007, s. 10). Następny element procesu komunikowania to kanał, czyli sposób, w jaki komunikat jest przekazywany do odbiorcy. Możemy dokonać rozróżnienia na dwa podstawowe rodzaje kanałów: komunikacja ustna i komunikacja pisemna. Komunikacja ustna może zachodzić: w cztery oczy, w małym zespole, przez telefon, przez wystąpienia publiczne i narady. Komunikaty ustne można dodatkowo podzielić na bezpośrednie (twarzą w twarz, obrady, negocjacje) i pośrednie (za pośrednictwem telefonu, telewizji, sieci komputerowej, komunikatory internetowe wykorzystujące dźwięk do porozumiewania się). Komunikacja pisemna to najczęściej różnego rodzaju notatki, e-maile, tekst na ekranie komputerowym, komunikatory internetowe itp. Następny etap procesu komunikowania to dekodowanie. Na zakłócenia interpretacji otrzymanego komunikatu nakładać się może m.in. indywidualna percepcja odbiorcy, niedostateczna uwaga, zmęczenie, napięcie. Odbiorcą komunikatów może być pojedyncza osoba, grupa osób (na przykład zebranie), pewien segment społeczny, do którego jest kierowany komunikat (na przykład reklama), konkretna organizacja itp.

W literaturze rozróżnia się różne rodzaje komunikacji. Najpowszechniejsze rozróżnienie to podział na: komunikację jednokierunkową oraz komunikację dwukierunkową.

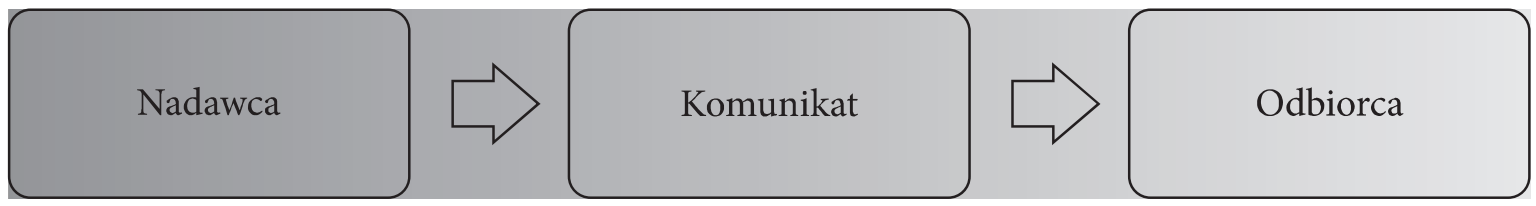

Rys. 1. Schemat komunikacji jednokierunkowej Źródło: opracowanie własne

Komunikacja jednokierunkowa jest szybsza i bardziej uporządkowana. Może być stosowana przy komunikatach krótkich i łatwych do dokładnego przekazania, wtedy, gdy rozmowa z odbiorcą jest trudna do nawiązania (duże zgromadzenia) lub w sytuacjach kryzysowych (np. pożar). Nie daje możliwości sprawdzenia, czy komunikat został właściwie zrozumiany. Nie daje możliwości reakcji ze strony odbiorcy.

Komunikacja dwukierunkowa wymaga więcej czasu i zaangażowania, jest niezbędna przy przekazywaniu komunikatów złożonych. Umożliwia sprawdzanie na bieżąco poziomu zrozumienia przekazywanych informacji oraz rozwiewanie niejasności. Pozwala na szybkie wychwytywanie błędów i reagowanie na nie. 
Umożliwia zarówno wzajemne zrozumienie, jak i kształtowanie partnerskich relacji. Przy komunikacji dwukierunkowej mówi się zatem, że występuje tzw. sprzężenie zwrotne pomiędzy nadawcą a odbiorcą. Zachodzi wtedy proces „komunikowania się" - odbiorca staje się nadawcą, a nadawca odbiorcą.

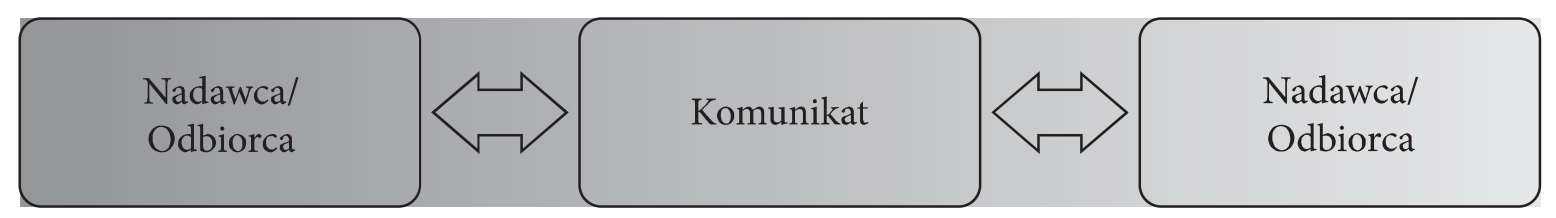

Rys. 2. Schemat komunikacji dwukierunkowej

Źródło: opracowanie własne

Kilka rodzajów sprzężenia zwrotnego wyróżnia J. Stankiewicz, np.:

- sprzężenie zwrotne szacowane (omawiana jest opinia i przedstawiane stanowisko w danej sprawie);

- $\quad$ sprzężenie zwrotne pozytywnie oceniające (okazanie aprobaty oraz podtrzymanie kontaktu);

- $\quad$ sprzężenie zwrotne negatywnie oceniające (wyjaśnienie niejasności, korygowanie błędów);

- $\quad$ sprzężenie zwrotne nieoceniające (brak wyrażania sądów i opinii, nastawienie na komunikaty partnera) (Stankiewicz, 2006, s. 56-57).

Ze względu na charakter przepływu informacji w strukturze organizacyjnej przedsiębiorstwa, możemy wyróżnić dodatkowo jeszcze trzy inne rodzaje komunikacji: pionową, poziomą i sieciową. Komunikacja pionowa odbywa się od góry do dołu lub od dołu do góry w hierarchii przedsiębiorstwa. Komunikacja pozioma odbywa się na tym samym szczeblu struktury organizacyjnej, czyli jest związana z przekazywaniem informacji pomiędzy pracownikami na równorzędnych szczeblach struktury organizacyjnej.

\section{Akt retoryczny i podstawowe narzędzia retoryki}

Coraz powszechniej na świecie uważa się, że w każdej dziedzinie sukces zależy od opanowania sztuki skutecznego komunikowania się werbalnego i niewerbalnego. Komunikacja społeczna rozumiana jest jako: przekazywanie informacji, umiejętności, pojęć, idei, myśli, uczuć, nawiązywanie i utrzymywanie kontaktów międzyludzkich, rozwiązywanie konfliktów, prowadzenie negocjacji, przekazywanie i kształtowanie opinii, prowadzenie kampanii politycznych, reklama, funkcjonowanie środków masowego przekazu - czyli posługiwanie się językiem w mowie i piśmie - oraz szerokie wykorzystanie pozajęzykowych środków wyrazu (Mały Słownik Języka Polskiego, 1993, s. 332). 
Dobra komunikacja sprawia, że ludzie wywierają na siebie wpływ, przekazując informacje o świecie i samych sobie. Informacje w postaci sygnałów stają się bodźcami wywołującymi różnorodne reakcje w zakresie myślenia, emocji i zachowań.

Aktualnie mamy dość niejednoznaczne spojrzenie na retorykę. $Z$ jednej strony ma ona złą opinię: często w prasie, radiu i telewizji banał i beztreściowość oraz mniej lub bardziej ozdobne gadulstwo bywa określone właśnie mianem retoryki. $\mathrm{Z}$ drugiej strony retoryka cieszy się niezwykłą wprost popularnością i mianem tym określa się wszystko, nawet treści, które nic z tym pojęciem nie mają wspólnego. Oprócz obiegowego i potocznego użycia terminu „retoryka”, ma ona jeszcze inne znaczenie - jako nauka funkcjonalnego i sprawnego posługiwania się językiem $\mathrm{w}$ mowie i piśmie, traktowana jako dziedzina interdyscyplinarna.

Arystoteles w Techne rhetorike, $\mathrm{w}$ postaci anegdoty przedstawił istotę retoryki: „Pewna kapłanka nie pozwalała synowi przemawiać na zgromadzeniu, mówiąc: - jeśli będziesz mówił prawdę, znienawidzą się ludzie, jeśli będziesz zaś mówił nieprawdę, znienawidzą cię Bogowie".

Dla nowych potrzeb można by to zinterpretować odwrotnie: „Powinniśmy przemawiać - bo jeśli będziesz mówił prawdę, będą Cię kochać Bogowie, a jeśli nieprawdę, pokochają cię ludzie" - czyli mieszać prawdę z fałszem - liczy się cel.

Warunkiem jednak takiego przekonywania jest akceptacja słuchacza, która jest istotą retoryki - czyli umiejętność przekonywania, takiego ułożenia słów, przedstawienia argumentów, by można było rozum przekonać o jakiejś prawdzie za pomocą takich pobudek, które zdolne są rozbudzić uczucia.

Kwintylian podał następującą definicję retoryki:

1. gr. Rhetorike, od rhetor - mówca,

2. ars bene dicendi lub ars bene dicendi scientia:

a. ars - wiedza, umiejętność, sztuka - a więc wytwarzanie słowa za pomocą znajomości reguł (rzemiosła),

b. bene - przysłówek ten oznaczał zarówno poprawność i jasność, jak i stosowność, czyli zgodność słowa z myślą, wyrażał też moralne i wychowawcze zadanie retoryki - „bene” było rozumiane jako godne uznania,

c. dicendi - imiesłów „mówienie” - dotyczył zarówno strony tekstowej, jak i wykonawczej (wygłaszanie).

Encyklopedia Powszechna PWN podaje następującą definicję retoryki: krasomówstwo, sztuka wymowy; nauka zasad pięknego i sprawnego wysławiania się, obejmująca prawidła doboru słów, konstrukcji zdań, posługiwania się figurami retorycznymi, umiejętnej argumentacji. Rozumiana jest jako sztuka pięknego i skutecznego przemawiania, sztuka wymowy. Współcześnie coraz częściej jest traktowana jako nauka o uwarunkowaniach i prawidłowościach przekonywania za pomocą tekstów słownych, mówionych lub pisanych. Ta nowa retoryka, w odróżnieniu od klasycznej, opiera się na empirycznych badaniach psychologiczno-socjologicznych (Encyklopedia Powszechna, 2000). W Ilustrowanym Słowniku Języka Polskiego, 
już w roku 1916, pod hasłem „retoryka” przeczytamy: „retoryka to nauka pięknego wypowiadania myśli” (Arct, 1916).

Centralne miejsce w mowie zajmuje osoba mówiąca - mówca, podmiot retoryczny - upoważniona do pouczania, dowodzenia i przekonywania. Jak zaznaczył Arystoteles, na każdą mowę składają się trzy elementy: mówca, przedmiot mowy i adresat (Ziomek, 1990, s. 290). Mowa jest grą dwóch osób: podmiotu retorycznego i słuchacza.

We wszystkich niemal podręcznikach eksponowana jako główna rola retoryki jest perswazja podmiotu retorycznego. Według Arystotelesa istnieją trzy rodzaje mów, ponieważ tyle jest właśnie rodzajów słuchaczy, ze względu na odbiorców zgromadzonych bądź na greckiej agorze (łac. forum), bądź na areopagu (sądzie) (Ziomek, 1990, s. 290).

Teoria retoryki wyróżnia trzy podstawowe rodzaje: doradczy, sądowy i pochwalny, a każdy z rodzajów ma odmienny cel.

1. Retoryka doradcza - łac. genus deliberatorum, polega na doradzaniu lub odradzaniu jakiegoś problemu czy sprawy. Głównym celem doradzania jest dobro i szczęście, pożytek. Rodzaj doradczy zawsze odnosi się do przyszłości.

2. Retoryka sądowa - łac. geus indiciale, obejmuje wypowiedzi perswazyjne odnoszące się do przeszłości, które oskarżają lub bronią, dowodzą, że coś jest prawdziwe lub nieprawdziwe. Celem oskarżenia jest przedstawienie dowodów winy, udowodnienie jej. Obrona polega na precyzyjnym zbijaniu zarzutów oskarżenia.

3. Retoryka popisowa - łac. genus demonstrativum, obejmuje wypowiedzi perswazyjne dotyczące czasu teraźniejszego, zawierające pochwałę albo naganę osób, rzeczy, wartości, zwłaszcza cnót. Pochwałę przeprowadza się według określonych schematów. Skuteczność pochwały jest wprost proporcjonalna do nagany zjawisk przeciwstawnych pochwale.

Trzy rodzaje retoryki (tria genera dicendi) nie występowały w formie czystej. W praktyce decydowała dominanta jakiegoś rodzaju. Praktyka wzajemnego przenikania się trzech rodzajów retorycznych jest niezwykle trudna do identyfikacji.

Retoryczna sztuka słowa oparta na umiejętności posługiwania się żywą mową obejmowała pięć działów, zawierających szczegółowy opis przygotowania, rozplanowania i wygłoszenia przemówienia. Była to wiedza o wynajdywaniu myśli, sztuka zaplanowania przemówienia i technika posługiwania się środkami językowo-stylistycznymi, traktowanymi zawsze jako narzędzie wysławiania się, inwencji i konwencji. Skomplikowaną mowę należało zapamiętać według wypracowanych reguł sztuki pamięci i wygłosić ją z zachowaniem sztuki wykonawczej.

Do podstawowych zasad sztuki retorycznej, odnoszących się do sposobu kształtowania komunikatu perswazyjnego, zaliczano:

- organiczność - wewnętrzny ład, zharmonizowanie i wzajemne dostosowanie poszczególnych części mowy; 
- stosowność - czyli takt retoryczny, wszechstronne uwzględnienie czynników z zakresu ważnych okoliczności towarzyszących wygłaszaniu mowy (miejsce, czas, przedmiot, cel, możliwości intelektualne itp.);

- funkcjonalność - nakaz świadomego i celowego posługiwania się retorycznymi środkami przekonywania.

Aby zakwalifikować jakiś akt jako „akt retoryczny”, akt ten musi być zamierzony (celowy), być odpowiedzią na określoną sytuację i być adresowany do odbiorców. $\mathrm{Na}$ podstawowe elementy aktu perswazyjnego składają się: kontekst (perswazja jako usytuowana), odbiorcy (perswazja jako adresowana), sytuacja lub potrzeba (perswazja jako respons), cel lub zamiar (perswazja jako zamierzona), elementy limitujące (perswazja jako rozwiązanie pewnego problemu).

W powyższym rozdziale wymienione zostały funkcje, które może pełnić w organizacji proces komunikacji. Korzenie wyodrębnienia tych funkcji języka sięgają starożytności, a dokładnie właśnie sztuki retoryki, gdzie miały odpowiadać trzem składniom psychiki człowieka: rozumowi (logos), uczuciu (pathos) oraz woli (ethos) (Pisarek, 2002, s. 15).

Na ethos składał się wizerunek nadawcy. Mówca musi nie tylko upewnić się, że jego argumentacja jest przekonująca, ale także musi stworzyć odpowiednie wrażenie o sobie i wprowadzić odbiorców w odpowiedni stan świadomości. Stwarzanie odpowiednich warunków do perswazji jest bardzo ważne. Mówca powinien wykazywać odpowiedni charakter, aby odbiorcy mieli wrażenie, że odnosi się do nich w odpowiedni sposób i dalej, aby sami odbiorcy mieli do niego określony stosunek. Charakter mówcy wykazany w samej mowie (szerzej: w akcie perswazyjnym). Wizerunek mówcy, wrażenie jego osoby, jakie powstaje w świadomości odbiorców jest najważniejszym elementem perswazyjnym. Ethos komunikowany jest poprzez słowa, symbole, wygląd, zachowanie, wrażenie, elementy dekoracyjne lub estetyczne itp.

Ethos nakłada się w pewnym zakresie na pathos poprzez psychologiczne zjawisko „odbicia” (http://retoryka.pl/index.php?site=hsite\&id=41). Podświadoma, instynktowna, niezależna od naszej woli ocena drugiego człowieka. Dokonujemy jej w ciągu zaledwie 20-30 pierwszych sekund znajomości, na podstawie wyglądu zewnętrznego i zachowania osoby - sposobu wypowiedzenia pierwszych słów i wykonania pierwszych gestów. Na pierwsze wrażenie składają się przede wszystkim ocena elementów komunikacji niewerbalnej (wygląd fizyczny, ubiór, fryzura, sposób zachowania, mimika, ton i barwa głosu, wyraz oczu). Pierwsze wrażenie to tak naprawdę jedynie nasze wyobrażenie na temat danej osoby, ponieważ jednak w proces ten angażujemy emocje, stąd zostaje ono w nas na dłużej i trudno je zmienić. Pierwsze wrażenie bez względu na to, czy negatywne, czy pozytywne zostaje głęboko zakodowane w naszej podświadomości, w dalszych kontaktach $\mathrm{z}$ daną osobą sugerujemy się zazwyczaj wcześniej ukształtowaną opinią. Jesteśmy więc skłonni przypisywać lub wręcz na siłę doszukiwać się pozytywnych cech potwierdzających naszą dobrą ocenę na temat tej osoby - efekt halo (aureoli). Będziemy również skłonni przypisywać/uwypuklać 
negatywne cechy danej osoby - efekt rogów, potwierdzając naszą negatywną ocenę na jej temat (czasami nawet wbrew logice).

Patos to emocjonalny aspekt aktu perswazyjnego. Istotą patosu jest wywołanie odpowiedniej postawy u odbiorcy, a to dlatego, że podejmujemy odmienne decyzje pod wpływem bólu czy radości, miłości czy nienawiści. Patos, jak etos, łączy się z charakterem, ale charakterem odbiorców, nie osoby mówiącej. Analiza patosu jest więc skierowana na analizę środków, za pomocą których przekaz wywołuje emocje, bądź odwołuje się do emocji odbiorców.

Etos i patos tworzą pewną całość, jakość perswazyjną, np. język, mimika czy obrazy mogą wywołać pewne emocje u jednych odbiorców, a całkiem inne emocje $\mathrm{u}$ innych odbiorców.

Logos to intelektualny, racjonalny element aktu perswazyjnego. To miejsce, gdzie dokonuje się argumentacja na poziomie treściowym. To obszar podstawowych założeń i strategii, obszar budowania schematów argumentacyjnych.

\section{Perswazja i argumentacja}

Perswazja z greckiego Peithein i łacińskiego Persuasio - przekonanie, wiara. Przekonać oznacza nadać cechy prawdy, prawdopodobieństwa, słuszności temu, co twierdzimy lub pozbawić tych cech tego, czemu zaprzeczamy. Perswazja jest zintegrowanym oddziaływaniem na umysł, wolę i uczucia słuchacza. Pojęcie perswazji znane jest w retoryce od starożytności i wiąże się z nakłanianiem, namawianiem, przekonywaniem, radzeniem itd. Mirosław Korolko pisze: „Przedmiotem perswazji może być każda sprawa podlegająca wartościowaniu intelektualnemu, etycznemu lub emocjonalnemu. Perswazja jest postępowaniem wartościującym, będącym wynikiem wielorako uwarunkowanych aksjomatów, norm, wzorców, ocen prawdy, dobra i piękna. (...) W perswazji prawda jest wartością, zaś jej przyjęcie wymaga świadomego i dobrowolnego wyboru między jedną a drugą wartością; przeciwieństwo bowiem jednej wartości nie przestaje być inną wartością. Sądy o wartościach wyrażają osobistą postawę autora sądu (perswadującego) wobec przedmiotu, którego sąd dotyczy" (Korolko, 1998, s. 33). Jak zatem sugeruje M. Korolko, w przedmiocie perswazji zawarte jest subiektywne wartościowanie, a także świadomość o jej stosowaniu osoby, do której jest ona skierowana. Efekt działania perswazyjnego, jakim jest zmiana postawy odbiorcy, jest zatem dobrowolnym wyborem. Mając to na uwadze, perswazje można określić jako: uświadomione poprzez obserwatora działanie werbalne nadawcy, dążące do zmiany postawy odbiorcy (Habrajska, 2005, s. 92).

Perswazja jest zjawiskiem powszechnym w życiu społecznym. Zdaniem G. Habrajskiej perswazja jest jednym $z$ najistotniejszych elementów integracji społecznej. „Poprzez stosowanie dyskursu pedagogicznego, duszpasterskiego, politycznego, reklamę itp., możliwe jest kształtowanie takiej postawy odbiorcy, która pozwoli mu 
na funkcjonowanie w określonej grupie" (Habrajska, s. 115). G. Habrajska osadza perswazję w takich procesach, jak:

- socjalizacja jednostki, która umożliwia dostosowanie do życia w określonej grupie,

- przyswajanie kultury własnego narodu i poznawanie obcych kultur,

- przyswajanie ideałów moralnych w dyskursie pedagogicznym,

- organizacja społeczeństwa, kształtowana w dyskursie politycznym,

- rozwój ekonomiczny.

Każda z tych dziedzin dyskursu ma swoje własne cele, które mogą, ale nie muszą pokrywać się ze sobą.

Działanie perswazyjne możemy podzielić na dwie fazy. W pierwszej fazie ma za zadanie doprowadzić do zmiany postawy grupy perswazyjnej, a w drugiej fazie wywołać oczekiwane zachowania. Ze względu na planowane cele, tradycyjnie wyróżnia się trzy cele perswazyjne oraz trzy rodzaje dyskursów perswazyjnych (Korolko, 1998, s. 34-44).

Trzy cele perswazji:

1. Pouczenie (łac. Docere), odnosi się do funkcji informacyjno-pouczającej i odwołuje się przede wszystkim do intelektu odbiorcy, do uzyskania jego zgody. Słuchacz powinien uwierzyć mówcy, że nie jest kłamcą.

2. Poruszenie odbiorcy (łac. Movere), odnosi się do oddziaływania na jego wolę, nakłaniania do czynu, wykonania, jest najważniejszym celem retoryki.

3. Zachwycenie słuchacza (łac. Delectare), ma na celu przepojenie perswazji przyjemnością estetyczną, głównie przez odwoływanie się do uczuć i emocji.

Rodzaje dyskursów perswazyjnych:

- Przekonywanie - sytuacja, w której mówiący chce wywrzeć wpływ na poglądy słuchacza, skłonić go do przyjęcia tezy według mówiącego lepszej niż ta, którą dotychczas odbiorca uważał za własną.

- Nakłanianie - sytuacja, w której mówiącemu chodzi o pozyskanie dla jakiegoś poglądu lub zespołu poglądów jak największej liczby zwolenników. Nakłanianie może być jawne lub ukryte, uczciwe lub nieuczciwe. Jeśli nakłanianie dotyczy doktryn politycznych, określa się je mianem propagandy. Jeśli chodzi o nakłanianie do zakupu określonych produktów, mówi się o reklamie. Jeśli zaś przedmiotem nakłaniania są pewne twierdzenia dotyczące interpretacji otaczającej nas rzeczywistości, nazywa się je dydaktyką.

- Pobudzanie - sytuacja, w której mówiącemu chodzi o doraźne zjednoczenie słuchaczy dla jakiejś sprawy czy poglądu. Nie zależy mu jednak na całkowitym przekonaniu odbiorcy, ale na skłonieniu ich do takiego działania, jak gdyby byli przekonani. Każde pobudzenie jest agitacją, opartą na autorytatywnym i sugestywnym dobieraniu słów prowadzących do wywoływania oczekiwanej relacji. 
Ideałem perswazji jest sytuacja, gdy słuchacz zaczyna się identyfikować $\mathrm{z}$ nadawcą. Rozmiar zmian przekonań odbiorcy, wywołanych poprzez przekaz perswazyjny zależy nie tyle od tego, co nadawca mówi, ile raczej od tego, co odbiorca mówi do siebie w wyniku otrzymania przekazu.

Przed przystąpieniem do fazy perswazji właściwej, niezbędne jest przygotowanie do niej odbiorcy. Działanie to odpowiada retorycznej fazie Inventio, która polega na odnajdywaniu stosownych do tematu myśli. Można powiedzieć, że inwencja jest to zdolność wynajdywania rzeczy prawdziwych lub prawdopodobnych, dzięki którym sprawa staje się wiarygodna. Każdy temat, który ma przedstawić mówca, powinien być pytaniem. Pytania te stanowią punkt wyjścia. Należy ustalić, czy pytania dotyczą ogólnej natury, tzn. tezy, czy też odnoszą się np. do określonej osoby, czasu, miejsca tzw. hipotezy. Zasadniczymi składnikami hipotezy są okoliczności. Kluczowym zadaniem inwencji jest odszukiwanie właściwych w danej sprawie argumentów. W tym celu konieczne jest określenie grupy perswazyjnej, w stosunku do której perswazja będzie stosowana (jaką wiedzą o obiekcie perswazji dysponuje odbiorca, jaki jest jego emocjonalny stosunek do tegoż obiektu). Gdy informacje te są już zgromadzone, następnym krokiem nadawcy jest przystąpienie do budowania więzi z odbiorcą (Habrajska, 2005, s. 120). Odbywa się ona na trzech płaszczyznach: kreowania dyspozycji odbiorcy, przygotowania emocjonalngo i kreowania wizerunku nadawcy - odpowiada zatem trzem podstawowym narzędziom retoryki: logosu, pathosu i ethosu.

Kreowanie wizerunku nadawcy związane jest $\mathrm{z}$ kształtowaniem retorycznego ethosu. Dla większości odbiorców osoba nadawcy (tzw. źródło przekazu) jest nierozerwalnie związana z treścią przekazu - stanowią całość przekazu perswazyjnego. Niezmiernie istotne, z punktu widzenia działań perswazyjnych, jest zatem zdobycie zaufania odbiorcy, wykreowanie odpowiedniego, wiarygodnego wizerunku. „U odbiorców nastawionych na źródło komunikatu, niewiarygodny nadawca nie wywoła żadnej zmiany poglądów, odbiorcy nastawieni na treść komunikatu mogą być przekonani przez nadawcę mniej wiarygodnego, ale tylko wówczas, gdy posługuje się on doskonałą argumentacją" (Szymanek, 2001, s. 231). Kreowanie wiarygodnego wizerunku nadawcy sprowadza się do podkreślenia jego kompetencji, walorów etycznych, szacunku do pełnionej przez niego roli społecznej, a także tworzenia więzi, wytworzenia kooperacji między nadawcą i odbiorcą.

Kreowanie dyspozycji odbiorcy do przyjęcia perswazji polega na wzbudzeniu zainteresowania odbiorem zamierzonych przez nadawcę treści. Istotne w tym działaniu jest to, by temat był dla odbiorcy interesujący. Kreując dyspozycje odbiorcy do przyjęcia perswazji, bardzo często bazuje się na wskazaniu możliwości uzyskania określonych korzyści lub poniesienia strat (Szymanek, 2001, s. 228-229). Zawsze w przypadku perswazji, wybór strategii zależy od grupy, do której jest ona skierowana.

Przygotowanie emocjonalne odbiorcy (pathos) do przyjęcia perswazji sprowadza się do wywoływania w nim odpowiednich uczuć, odpowiedniego stanu 
emocjonalnego, np. wściekłości lub radości (uniesienia) z jakiegoś powodu. „Wywołanie silnych emocji prowadzi do obniżenia krytycyzmu odbiorcy i umożliwia dominację nadawcy" (Habrajska, 2005, s. 122). Wywołanie emocji negatywnych odbiorcy można osiągnąć np. przez:

- jego intelektualne lub moralne deprecjonowanie,

- $\quad$ wywołanie jego lęku, respektu, uległości itp.

Z kolei wywołanie emocji pozytywnych odbiorcy można uzyskać, stosując:

- komplementowanie,

- podkreślanie ważności kontaktu itp.

Pozytywny stan emocjonalny np. zadowolenia, rozbawienia, zwiększa tolerancję, co ma wpływ na zwiększenie akceptowalności przesłanek i konkluzji, natomiast stan rozdrażnienia przyspiesza podjęcie decyzji destrukcyjnej.

Jako przykład wymienić można kilka podstawowych zasad perswazyjnych związanych z kształtowaniem odpowiedniego ethosu (kreowania wizerunku nadawcy) oraz pathosu (odpowiedniego emocjonalnego nastawienia odbiorcy):

1. Zasada sympatii - Sympatia jest podstawą stosunków międzyludzkich. Jeśli komuś się ufa i kogoś lubimy, łatwiej będzie ulegać jego wpływom niż osobom, które są zupełnie obce. Dlatego też, jeśli celem jest przekonanie kogoś obcego do danych racji, należy sprawić, aby nas polubił. Jesteśmy podatni na perswazję w takim stopniu, w jakim lubimy osobę, której mielibyśmy ulec. Pomóc w tym może np.: komplementowanie za pomocą osoby trzeciej; prośba innych o radę (wyrażam tym samym uznanie dla ich wiedzy i mądrości); sygnały niewerbalne (uśmiechanie się, kiwanie głową, utrzymanie kontaktu wzrokowego); dostosowanie poglądów do poglądów osoby mówiącej (efekt halo); atrakcyjność fizyczna; umniejszanie własnych osiągnięć (publicznie wyrażana wdzięczność wobec innych) (Cialdini i in., 2006, s. 291).

2. Magia słów - Jest to zasada szeroko stosowana wśród polityków, biznesmenów, a także księży. Unaocznia się poprzez zwroty typu: drodzy bracia, drodzy przyjaciele. Lubi się tych, którzy okazują sympatię i przełamali bariery obcości, gdy ktoś nazywa nas przyjacielem, dobrym człowiekiem, łatwiej jest się do tego kogoś przekonać, a co za tym idzie, jest się wtedy bardziej podatnym na ich wpływy. Magia słów ma na celu stwarzanie wrażenia „wspólnoty” pomiędzy sobą a słuchaczami. Poczucie wspólnoty jest często stwarzane przez użycie zaimka osobowego w liczbie mnogiej „my”, „nasz”, np. „my Polacy”, „my członkowie partii”, „my społeczeństwo”, „, nasz zespół”, „my jedna drużyna”, „nasz cel”, „nasze dobro” itp. (Cialdini i in., 2006, s. 449).

3. Siła imienia - Chętniej ulega się wpływom tych, którzy pamiętają nasze imiona, szczególnie jeśli są to osoby, które dopiero co poznaliśmy. To wywiera na odbiorcach wrażenie. Niejednokrotnie sztuczka ta jest stosowana 
w relacjach i korespondencji biznesowej, ponieważ skutecznie przełamuje oficjalny charakter i pomaga zjednać sobie odbiorców (Cialdini i in., 2006, s. 335).

4. Autorytet - Dużo łatwiej jest zaufać autorytetom i ludziom o dużym doświadczeniu, niż tym, którzy go nie posiadają. Dlatego chętniej wybierane są te rozwiązania, które były rekomendowane przez osoby będące ekspertami w swoich dziedzinach (Cialdini i in., 2006, s. 234).

5. Wzajemność - Zasada wzajemności bazuje na potrzebie odwdzięczania się. Jeśli ktoś zrobił komuś przysługę, ten czuje się zobowiązany i odczuwamy potrzebę, by się odwdzięczyć. Chęć rewanżu powoduje, że bardziej ulega się wpływom, jest to kierowane chęcią odwzajemnienia wcześniejszej dobroci (Cialdini i in., 2006, s. 318).

6. Podobieństwa - Sympatie odczuwa się dużo łatwiej i szybciej do ludzi podobnych do nas. Chodzi tu głównie o aspekty światopoglądowe, wygląd zewnętrzny, wykształcenie, zainteresowania. W przypadku relacji dalszych, biznesowych czy koleżeńskich, istotą skutecznej perswazji jest właśnie podobieństwo ludzi do siebie (Cialdini i in., 2006, s. 302).

7. Niedostępność - Dużo większym zainteresowaniem cieszą się te dobra, które są rzadkie, niedostępne, takie, których nie mogą mieć inni. Czas i ograniczoność dóbr to ich doskonała reklama, a zatem i skuteczne narzędzie perswazji (Cialdini i in., 2006, s. 270).

8. Fakty - Logika i nawiązywanie do faktów sprzyjają budowaniu dobrego wrażenia i sprawiają, że osoba nadawcy postrzegana jest jako kompetentna, posiadająca wiedzę, specjalizująca się w danej dziedzinie. Jest to szczególnie ważne podczas wystąpień publicznych i prezentacji (Cialdini i in., 2006, s. 205).

9. Społeczna słuszność - Większoośc ludzi postępuje tak, jak robią inni ludzie. Często nie będąc pewnym co do słuszności swojej decyzji, ulega się wpływowi innych. Łatwo ulega się grupie, kiedy większość osób wybrała jakieś rozwiązanie, reszta także się podporządkowuje (Cialdini i in., 2006, s. 296).

10. Mowa ciała - Głównym celem zasady wykorzystującej mowę ciała jest nawiązanie kontaktu, dopasowanie się do rozmówców pod względem fizycznym (postawa ciała, gesty, ruchy), ale też sposobem mówienia (ton głosu, tempo mówienia), czy sposobem oddychania (Cialdini i in., 2006, s. 179).

\section{Podsumowanie}

Argumentacja i perswazja są podstawą funkcjonowania tzw. społeczeństwa informacyjnego, w którym przepływ informacji ma szerokie zastosowanie w życiu codziennym, gospodarce, polityce oraz kulturze czy biznesie. Bez komunikacji niemożliwa byłaby organizacja życia społecznego, życia rodzinnego czy funkcjonowania 
przedsiębiorstw. Jest ona podstawą wymiany myśli i współdziałania, od niej zależy funkcjonowanie zarówno pojedynczych jednostek, jak i całych organizacji.

Dobra komunikacja wewnątrz firmy jest podstawą jej funkcjonowania, stanowi remedium na wszelkie możliwe trudności związane $\mathrm{z}$ zarządzaniem kadrą pracowniczą. Zwiększa zaangażowanie pracowników, utożsamia się z celami firmy, dobrze poinformowani pracownicy czują się docenieni, zmniejsza się ich opór wobec proponowanych zmian. Prawidłowa komunikacja wewnątrz firmy jest więc jednym z najważniejszych narzędzi zarządzania, narzędziem zapewniającym efektywne działanie. Skuteczne zarządzanie procesami komunikowania się oraz wysokie kompetencje $\mathrm{w}$ zakresie komunikacji perswazyjnej to jedne z podstawowych i najważniejszych zadań menadżerów. Retoryka dostarcza nieograniczony zasób zasad, metod, chwytów, struktur umożliwiających maksymalizowanie potencjalnych korzyści płynących z poprawnej, jasnej i nastawionej na konkretny cel perswazyjnej komunikacji. Jednocześnie znajomość tych zasad jest środkiem do minimalizowania ewentualnych problemów czy przezwyciężania barier komunikacyjnych. Brak znajomości reguł retorycznych stosowanych $w$ celu uskutecznienia komunikacji jest jedną z najpoważniejszych przeszkód na drodze do efektywnej działalności grupowej.

$\mathrm{W}$ ostatnich latach zainteresowanie problematyką perswazji, argumentacji i retoryki w ramach szeroko pojętej komunikacji wyraźnie wzrasta. XXI wiek określony został epoką pokolenia informacyjnego, pokolenia, które charakteryzuje ciągłe usprawnianie procesów przekazywania, odbioru i rozumienia informacji. Towarzyszy temu bardzo szybkie tempo rozwoju technologii, narzędzi i środków wspierających komunikowanie się, a wszystko to ma na celu zwiększenie efektywności komunikacji, efektywności porozumiewania się. Inwestowanie w skuteczną komunikację, czyli komunikację, dzięki której osiągnięty zostanie założony cel perswazyjny, może przynieść wiele korzyści. Natomiast ignorancja i lekceważenie jakości komunikacji mogą przynieść klęskę i duże straty.

\section{BIBLIOGRAFIA}

[1] DaIr J., 2000, Anatomia Biznesu. Komunikacja, Wyd. Studio EMKA, Warszawa.

[2] Arct M., 1916, Ilustrowany Słownik Jezyka Polskiego, Wyd. A. Arcta, Warszawa.

[3] Cialdini R.B., Kenrick D.T., Neuberg S.L., 2006, Psychologia społeczna, Rozwiązane tajemnice, Wyd. GWP, Gdańsk.

[4] Doмасноwsкi W., 1991, Interakcyjny model funkcjonowania społecznego, społeczna psychologia kliniczna, Wyd. PWN, Warszawa.

[5] Encyklopedia Powszechna, 2000, Wyd. PWN, Warszawa.

[6] Guetzkow H., 1965, Communications in organizations, Chicago.

[7] Habrajska G., 2005, Nakłanianie, perswazja, manipulacja językowa, „Acta Universitatis Lodziensis", $\mathrm{Nr} 7$.

[8] Korolko M., 1998, Sztuka retoryki (przewodnik encyklopedyczny), Wyd. Wiedza Powszechna, Warszawa. 
[9] Malinowski B., 1987, Ogrody koralowe i ich magia. Język magii i ogrodnictwa, [w:] „Dzieła”, t. 5, Wyd. PWN, Warszawa.

[10] MaŁy SŁownik Języka Polskiego, 1993, Wyd. PWN, Warszawa.

[11] MasŁYK-Musia£ E., 1975, System informacji w przedsiębiorstwie przemystowym, Wrocław.

[12] Ober J., 2013, Funkcja i rola efektywnej komunikacji w zarządzaniu, „Zeszyty Naukowe Politechniki Śląskiej”.

[13] Ober J., 2007, Informacja i komunikacja w zarządzaniu, Wyd. Politechniki Śląskiej, Gliwice.

[14] Pisarek W., 2002, Żeby nas czytano, [w:] Nowa retoryka dziennikarska, Wydawnictwo Universitas, Kraków.

[15] SHUteR R., 1979, Understanding misunderstandings: Exploring interpersonal communication, New York.

[16] Stankiewicz J., 2006, Komunikowanie się w organizacji, Wyd. „Astrum”, Wrocław.

[17] Szewczyк A., 2004, Informacja - dobra lub zła nowina, Wyd. „Hogben”, Uniwersytet Szczeciński, Szczecin.

[18] Szymanek K., 2001, Sztuka argumentacji. Słownik terminologiczny, Wyd. PWN, Warszawa.

[19] Zıомек J., 1990, Retoryka opisowa, Wrocław-Warszawa-Kraków, Wyd. Zakład Narodowy im. Ossolińskich.

\section{NETOGRAFIA}

[1] http://retoryka.pl/index.php?site=hsite\&id=41 (29.03.2017). 
